\title{
Z problematyki nazewnictwa grzybów wielkoowocnikowych w języku ukraińskim i polskim — przegląd źródeł
}

Barbara Gumińska — botanik i mykolog, autorka licznych prac z zakresu mykologii ${ }^{1}$ - w jednym z artykułów poświęconych grzybom wielkoowocnikowym charakteryzuje je następująco:

Nazwą macromycetes (wielkoowocnikowe) obejmujemy grzyby tworzące owocniki, które możemy w przyrodzie dostrzec gołym okiem, choć niektóre z nich mogą mieć bardzo małe rozmiary (np. miseczki-apotecja u workowców). Na ogół jednak są to grzyby pokaźnych rozmiarów, o owocnikach mających różną konsystencję: drewnowatą lub skórzastą (np. huby), mięsistą (np. gołąbki, muchomory, pieczarki), galaretowatą (np. trzęsakowate) lub inną ${ }^{2}$.

Większość narodów Europy Środkowej i Wschodniej czy krajów Dalekiego Wschodu ze względu na swój stosunek do zbierania i przetwarzania grzybów wielkoowocnikowych zalicza się do społeczeństw mykofilicznych ${ }^{3}$, a wielowiekowe tradycje grzybiarskie znajdują odzwierciedlenie w ich kulturze i języku.

Stwierdzenie to w szczególny sposób odnosi się do rzeczywistości polskiej i ukraińskiej. Leksyka mykologiczna obecna w ukraińskich i polskich przysłowiach i porzekadłach ludowych, literaturze pięknej, tekstach naukowych czy lite-

${ }^{1}$ Między innymi kilkukrotnie wznawianej publikacji napisanej wspólnie z Władysławem Wojewodą: Grzyby i ich oznaczanie, Warszawa 1985. Praca ta jest bardzo ceniona przez polskie środowisko mykologów i grzybiarzy.

2 B. Gumińska, Grzyby wielkoowocnikowe (macromycetes), [w:] Flora i fauna Pienin, red. J. Razowski, „Monografie Pienińskie” 1, Kraków 2000, s. 47-53.

${ }^{3}$ Podział społeczeństw na mykofiliczne (narody Europy Środkowej i Wschodniej, kraje Dalekiego Wschodu Azji) i mykofobiczne (głównie kraje germańskie Europy Zachodniej) zaproponował R. Gordon Wasson — twórca etnomykologii. Zob. https://web.archive.org/web/20090416234856/ http://www.huh.harvard.edu/libraries/wasson.html (dostęp: 15.04.2016). 
raturze popularnonaukowej jak dotąd nie doczekała się kompleksowego opracowania, a sam temat nie jest eksploatowany przez językoznawców. Wydaje się, że należałoby zmienić ten stan rzeczy między innymi ze względu na kulturę i tradycje obu narodów oraz wielowiekowe funkcjonowanie słownictwa mykologicznego na gruncie języka polskiego i ukraińskiego. To, że terminy mykologiczne czy, szerzej, elementy słownictwa mykologicznego są stałym komponentem językowym pewnych płaszczyzn funkcjonowania człowieka, przenikając różne, niekiedy zupełnie ze sobą niezwiązane dziedziny życia, jest wystarczającą przesłanką, aby ów zbiór słownictwa usystematyzować i opisać.

Celem niniejszego artykułu jest omówienie ukraińskich i polskich źródeł słownictwa mykologicznego. Prezentacja zebranego materiału ma być nie tylko „sprawozdaniem" ze wstępnego etapu prac przed planowanymi szeroko zakrojonymi i wieloaspektowymi badaniami słownictwa mykologicznego, lecz także zasygnalizowaniem potrzeby takich analiz. Z punktu widzenia polskiego ukrainisty szczególnie ciekawie rysuje się bowiem kwestia konfrontacji leksyki ukraińskiej i polskiej, zwłaszcza że badania porównawcze w tej sferze słownictwa nie były dotąd prowadzone.

Funkcjonowanie słownictwa mykologicznego, a w szczególności nazw grzybów (mykonimów ${ }^{4}$ ), na poziomie tekstu sprowadza się do jego obecności w kilku obszarach, z których najważniejsze wydają się zasygnalizowane wyżej: prace naukowe (z różnych dziedzin, nie tylko w rozprawach z zakresu mykologii) i popularnonaukowe, teksty literackie i sfera ludowości. Każda z wymienionych stref stanowi dla lingwisty potencjalne źródło bogatych zasobów materiałowych, a badania językoznawcze można prowadzić na wielu polach. O konieczności zainicjowania kontrastywnych badań frazeologicznych i paremiologicznych, ukierunkowanych na słownictwo mykologiczne, świadczy choćby poniższe zestawienie przysłów oraz jednostek frazeologicznych, sporządzone w oparciu o wiedzę autora:

Bez ryba i grzyba umarłby kaszeba

Łaknąć jak kania dżdżu ${ }^{5}$

Dwa grzyby w barszcz

Gdzie jeden grzyb, tam i drugi
Гриби шукають — по лісу гасають

Де дуби, там і гриби

Де один грибок, там цілий вінок

Дощ іде - гриби будуть

${ }^{4}$ Termin ten pojawił się w pracy Tetiany Czernysz: Нариси зі слов 'янської порівняльноісторичної лексикології та етимологї̈ w 2010 roku. Zob. T.O. Черниш, Нариси зі слов 'янської порівняльно-історичної лексикології та етимології, Київ 2010, s. 121, 277.

${ }^{5}$ Znaczenie przytoczonej frazy, a co za tym idzie wyrazu kania, może być dwojakie (grzyb — ptak); jej interpretacji nie podjęto się na stronie internetowej Rady Języka Polskiego, wskazując jako źródła zarówno Stownik języka polskiego pod redakcją Mieczysława Szymczaka czy Stownik języka polskiego pod redakcją Witolda Doroszewskiego (kania $\rightarrow$ grzyb), jak i Uniwersalny stownik języka polskiego pod redakcją Stanisława Dubisza (kania $\rightarrow$ ptak); zob. http://www.rjp.pan.pl/ index.php?option=com_content\&view=article \&id=681:akn-jak-kania-ddu\&catid=44\&Itemid=145 (dostęp: 15.07.2016). Rozstrzygnięcia tej kwestii nie podejmuje się między innymi Jan Miodek 
Gdy grzyby wielkie korzenie mają, wielką zimę zapowiadają

Gdy we wrześniu grzybów brak, niezawodny zimy znak

Gdy rok grzybowy, to nie chlebowy

Gdy się grzyby zrodzą, chleba mało

Grzybki smaczne, ale nie ze wszystkim zdrowe

Kiedy nie ma ryb, dobry i grzyb

Lepszy rydz niż nic

Na święty Łukasz próżno grzybów szukasz; lecz rydz jeszcze się zawadzi, jeżeli go mróz nie zdradzi

Wrzesień chodzi po rosie, zbiera grzyby we wrzosie

Wyrastają, jak grzyby po deszczu

Zdrowy jak rydz
Жди, грибе, може, тебе хтось здибле

Зі щастям добре і по гриби ходити

3'явилися опеньки - літо закінчилося

I гриба знайти треба мати щастя

Їж борщ з грибами, і держи язик за зубами

Коли грибно, то і хлібно

Назвався грибом - лізь у кошик

Не зігнешся до землі, то й гриба не знайдеш

Не тепер по гриби ходити, але восени, як будуть родити

Про гриб не згиб

Увечері дощі — вранці грибів чекай

Kwestia nazewnictwa grzybów na poziomie dialektów języka ukraińskiego i polskiego to odrębny i niezmiernie intrygujący problem badawczy — należałoby zwrócić uwagę na regionalne, lokalne nazwy grzybów, które niejednokrotnie w znacznym stopniu odbiegają od nazw oficjalnych, oraz synonimię i homonimię wśród mykonimów, ciekawe byłyby tutaj badania w zakresie etymologii — zarówno na poziomie poszczególnych języków, jak i ich konfrontacja. Analizy dialektologiczne w zakresie omawianej leksyki, w szczególności badania terenów pogranicza ukraińsko-polskiego, zestawienie ich rezultatów z innymi obszarami (w przyszłości może z terytorium całej Słowiańszczyzny) mogłyby przynieść interesujące efekty między innymi w postaci artykułów, monografii czy map.

Jednakże nie tylko tradycja i mądrość ludowa odwołuje się do słownictwa czy realiów grzybiarskich. Tematyka związana z grzybami wielkoowocnikowymi, grzybobraniem niejednokrotnie stanowiła element (a czasem nawet wątek główny) dzieł poetyckich czy prozatorskich. Stwierdzenie to dotyczy zarówno polskiej, jak i ukraińskiej literatury pięknej.

Warto zauważyć, że elementy słownictwa mykologicznego zajmują szczególne miejsce w utworach skierowanych do najmłodszych czytelników. Leksyka związana z przyrodą jest bowiem ważnym punktem wychowania przedszkolnego

(zob. http://plus.gazetawroclawska.pl/opinie/a/rzecz-o-jezyku-laknac-jak-kania-dzdzu,12311511 [dostęp: 9.08.2017]), odwołując się jednakże do argumentacji kulturoznawców, folklorystów, w tym Juliana Krzyżanowskiego (kania $\rightarrow$ ptak, zob. Nowa księga przysłów polskich, red. J. Krzyżanowski, Warszawa 1969, s. 20). „Ornitologiczna” proweniencja przysłowia potwierdza się w kaszubskich obrzędach ścinania kani (zob. m.in. L. Bielawski, A. Mioduchowska, Kaszuby, cz. 1. Pieśni obrzędowe, Warszawa 1997, s. 217-218). 
i wczesnoszkolnego, stąd obecność mykonimów i szerzej - słownictwa związanego z grzybami i lasem w wielu utworach dedykowanych właśnie dzieciom. Spośród autorów polskich, którzy do swych utworów wplatali komponenty mykologiczne, należy wymienić chociażby: Jana Brzechwę $e^{6}$, Hannę Ożogowską ${ }^{7}$, Stefanię Szuchową ${ }^{8}$, Zygmunta Marka Miszczaka ${ }^{9}$ oraz Marię Terlikowską ${ }^{10}$. Ukraińscy twórcy poezji dziecięcej równie chętnie sięgają do omawianego słownictwa, są to na przykład: Tetiana Czornowi1 ${ }^{11}$, Natalia Kapustiuk ${ }^{12}$, Ołeksandr Prokofiew ${ }^{13}$, Wołodymyr Stepanow ${ }^{14}$ i Walerij Szulżyk ${ }^{15}$.

Poezja przeznaczona dla dorosłych odbiorców również zawiera elementy słownictwa mykologicznego, niekiedy natomiast grzyby stanowią lejtmotyw tych utworów, na przykład we fraszkach Jana I. Sztaudyngera ${ }^{16}$ czy bajce Iwana Nemyrowycza ${ }^{17}$.

„Słownictwo grzybiarskie” współtworzy też niepowtarzalny klimat dzieł autorów zaliczanych do panteonu obu literatur. Stwierdzenie to dotyczy nie tylko klasyków literatury, jak Adam Mickiewicz ${ }^{18}$, lecz także twórców współczesnych, jak na przykład Serhij Żadan ${ }^{19}$.

Wszystkie utwory o tematyce „grzybiarskiej” wspomnianych autorów zawierają komponenty, które można odnieść do słownictwa mykologicznego — są to głównie nazwy grzybów wielkoowocnikowych bądź leksemy nieco luźniej związane z omawianym tematem.

\footnotetext{
${ }^{6}$ Zob. J. Brzechwa, Grzyby, Warszawa 2014, s. 3-10.

${ }^{7}$ Zob. H. Ożogowska, A to kapelusz, [w:] Wierszyki dla dzieci, Warszawa 2001, s. 16.

${ }^{8}$ Zob. S. Szuchowa, Borowik, http://przedszkolak.blogspot.com/2007/10/wiersz-borowik. html (dostęp: 17.05.2016).

${ }^{9}$ Zob. Z.M. Miszczak, O czym Jaś nie przeczytał $w$ atlasie, http://wierszykidladzieci.pl/ miszczak/atlas-grzybow.php (dostęp: 17.05.2016).

${ }^{10}$ Zob. M. Terlikowska, Jestem jesien, http://dzieci.epapa.pl/wiersze/7037.html (dostęp: 17.05.2016).

11 Zob. Т. Чорновіл, Сироїжки, Маслюк, Глива, Опеньок, Боровик, Зеленуха, Польський гриб i in., http://probapera.org/publication/13/6578/virshyky-u-koshyku.html (dostęp: 17.05.2016).

12 Zob. Н. Капустюк, Бліда поганка, Боровик, Маслюк i in., http://allforchildren.com.ua/ index_mushrooms1.htm (dostęp: 17.05.2016).

$\overline{13}$ Zob. О. Прокоф'єв, Боровик, Опеньок і in., http://allforchildren.ru/poetry/index_mushrooms.php (dostęp: 17.05.2016).

${ }^{14}$ Zob. В. Степанов, Маслюки, Підберезник і підосичник i in., http://allforchildren.com.ua/ mushrooms0141.htm (dostęp: 17.05.2016).

15 Zob. В. Шульжик, Дощьовик, Мухомор і in., http://allforchildren.com.ua/mushrooms0141. htm (dostęp: 17.05.2016).

${ }^{16}$ Zob. J.I. Sztaudynger, Do borowika, Boletus rufus, Do maślaka, Opinia i rzeczywistość, Kurki, Bajka o grzybach, Do towarzyszy grzybiarzy, Niewdzięcznik i in., https://idziemy.nagrzyby. $\mathrm{pl} /$ index.php?artname $=$ stories\&artmid $=$ content\&id $=2519$ (dostęp: 17.05 .2016$)$.

17 Zob. I. Немирович, Кабан і гриби, http:/gumoreska.org.ua/baiki/baiki-virshi/277-kaban-gribi.html (dostęp: 17.05.2016).

18 Zob. A. Mickiewicz, Pan Tadeusz, księga 3. Umizgi, Warszawa 1984, s. 81-82.

19 Zob. С. Жадан, Гриби Донбасу, http://tisk.org.ua/?p=13188 (dostęp: 18.05.2016).
} 
Utwory literackie są probierzem społecznej żywotności słownictwa mykologicznego zarówno w czasie (badania dzieł z różnych epok literackich), jak i przestrzeni (terytoria obejmujące funkcjonowanie języka ukraińskiego i polskiego). Wymienione tu utwory świadczą o ,potencjale mykologicznym” obu literatur, a dalsza eksploracja w tym kierunku oraz definiowanie obszarów konfrontacji wydają się wskazane $\mathrm{i}$ - podobnie jak w sferze paremiologii czy dialektologii zapewne zaowocują wieloma opracowaniami.

Do źródeł, które stanowią istotę pracy lingwisty w tym obszarze leksykalnym, należy jednak zaliczyć głównie prace naukowe i popularnonaukowe z dziedziny mykologii, które można przyporządkować do dwóch grup:

1) prace poświęcone grzybom w najszerszym rozumieniu problematyki mykologicznej, w przeważającej części skupiające się jednak na grzybach makroskopijnych, na przykład: Aliny Skirgiełło, Władysława Wojewody, Barbary Gumińskiej, Mariji Zerowej, Solomona Wassera czy Iryny Dudki ${ }^{20}$;

2) prace z innych dziedzin nauki ważnych dla życia człowieka (głównie medycyny, fitopatologii, medycyny weterynaryjnej i budownictwa), w których tematyka mykologiczna pojawia się przy omawianiu problemów istotnych dla tych dyscyplin, na przykład: Eugeniusz Baran, Zarys mikologii lekarskiej; Józef Kochman, Zarys mikologii dla fitopatologów; Zdzisława Libudzisz, Krystyna Kowal, Zofia Żakowska, Mikrobiologia techniczna; Joanna Marcinkowska, Oznaczanie rodzajów grzybów ważnych w patologii roślin; Д.В. Леонтьев, А.Ю. Акулов, Загальна мікологія; І.Л. Марков, Практикум із сільськогосподарської фітопатологї̈; І.І. Мавров, І.А. Безрученко, Л.Д. Калюжна, Культуральна діагностика дерматомікозів: Методичні рекомендації ${ }^{21}$.

Nie można jednocześnie zapominać o źródłach leksykograficznych, takich jak słowniki objaśniające, terminologiczne, dwujęzyczne, dialektologiczne, leksykony, encyklopedie, które również mogą okazać się cennym materiałem badawczym.

Wszystkie wymienione źródła stanowią niezwykle różnorodny materiał, którego wieloaspektowe opracowanie językoznawcze, zwłaszcza w proponowanym tu ujęciu konfrontatywnym, może stanowić pole do rozważań dla lingwistów na lata.

Szczególne miejsce wśród publikacji o charakterze mykologicznym zajmują prace popularnonaukowe: atlasy i przewodniki dedykowane grzybiarzom niezwykle ważne źródło dla badań konfrontatywnych opierających się na bazie leksykalnej języka ukraińskiego i polskiego. Ich struktura jest uniwersalna dla większości wydawnictw tego typu (na opis danego gatunku grzyba składają się zwykle: nazwa(-y) oficjalna(-e) grzyba, nazwa(-y) regionalna(-e), nazwa(-y) łacińska(-ie), wygląd, występowanie, możliwości pomyłki z innymi gatunkami, informacje kulinarne, ciekawostki itp.). Nie wszystkie z nich można jednak wykorzystać jako materiał do analiz. Niemniej w przypadku badań nad nazewnictwem

${ }^{20}$ Wykaz wybranych prac poszczególnych autorów zamieszczono w bibliografii.

${ }^{21}$ Informacje dotyczące miejsca i roku wydania publikacji zamieszczono w bibliografii. 
grzybów wielkoowocnikowych pochylenie się nad tymi publikacjami jest wręcz nieodzowne, gdyż prócz słownictwa same w sobie stanowią one już gotowy i uporządkowany materiał do konfrontacji. W większości prace te reprezentują wysoki poziom merytoryczny, a w ostatnich latach również edytorski. Grono autorów z reguły stanowią mykolodzy, licencjonowani grzyboznawcy i pasjonaci grzybiarstwa, między innymi: Władysław Wojewoda, Wiesław Kamiński, Patrycja Zarawska, Sławomir Sokół, Marek Snowarski, Maryna Suchomłyn, Weronika Dżahan, Marija Zerowa czy Salomon Wasser. Już same książki wymienionych autorów mogą stanowić minimum materiałowe dla prac porównawczych, a z pewnością są gwarancją rzetelności i wszechstronnego podejścia do problematyki macromycetes. Uzupełnieniem mogą być autorskie strony internetowe poświęcone grzybom i grzybiarstwu ${ }^{22}$.

Wszystkie przytoczone źródła są dowodem na to, że przed językoznawcą rysuje się niezmiernie ciekawa perspektywa badań konfrontatywnych na poziomie semantycznym, słowotwórczym, onomastycznym, diachronicznym czy dialektologicznym.

Mimo tak szerokiego opracowania tematyki mykologicznej, a zwłaszcza problematyki grzybów makroskopijnych, oraz faktu, iż kwestie te są stałym elementem funkcjonowania naszych społeczeństw, zastanawiającym jest, że językoznawcy (zarówno polscy, jak i ukraińscy) w sposób kompleksowy nie zajęli się dotąd sferą nazewnictwa grzybów. Badania w tym zakresie są raczej jednostkowe, a braku polsko-ukraińskich prac porównawczych bynajmniej nie rekompensują sporadyczne badania polskich i ukraińskich uczonych poświęcone nazwom grzybów rozpatrywanym w różnych aspektach: Barbary Bartnickiej-Dąbkowskiej, Ewy Referowskiej-Chodak, Kazimierza Kopczyńskiego i Marii Ławrynowicz, Jerzego Kuźmiuka, Maryny Tkaczuk, Rusłany Omelkoweć, Wołodymyra Kurylenki (regionalne i ludowe nazwy grzybów); Andrzeja Chlebickiego i Jerzego Kuźmiuka (etymologia); Ludmyły Symonenko (leksykologia); Iryny Dudki i Zwenysławy Kałyneć-Mamczur (terminologia i leksykografia) ${ }^{23}$. Prace wymienionych badaczy, choć stosunkowo nowe, bo z reguły zamykające się w przedziale ostatnich 20 lat, w większości koncentrują się na kwestiach nazewnictwa regionalnego, a przecież, co starano się wskazać w niniejszym tekście, obszarów do prowadzenia ewentualnych badań jest zdecydowanie więcej.

Przedstawione w artykule źródła są wyraźnym potwierdzeniem tezy, iż słownictwo mykologiczne jest stałym elementem ukraińskich i polskich tekstów różnego typu. Biorąc pod uwagę potencjał materiału źródłowego i zakres jego interpretacji, należy stwierdzić, że badania nad nim (jak dotąd prowadzone przez polskich i ukraińskich językoznawców w dość wąskim zakresie) wydają się nieodzowne.

${ }^{22}$ Zob. np. cybertruffle.org.uk/ukrafung/ukr/ (Гриби України) T. Adrianowej i D.W. Mintera; grzyby.pl M. Snowarskiego; nagrzyby.pl W. Kamińskiego.

${ }^{23}$ Wykaz wybranych prac poszczególnych autorów zamieszczono w bibliografii. 
Słownictwo mykologiczne funkcjonuje głównie w czterech obszarach: 1) prace naukowe $z$ mykologii, ale i innych dziedzin (botaniki, biologii, medycyny, medycyny weterynaryjnej, budownictwa itd.), w których słownictwo mykologiczne realizuje się, co charakterystyczne, przede wszystkim w postaci wyspecjalizowanych terminów; 2) prace popularnonaukowe, to znaczy atlasy grzybów i przewodniki autorstwa mykologów i licencjonowanych grzyboznawców, pozycje o, w większości, wysokim poziomie merytorycznym i edytorskim; 3) utwory literackie różnego typu — od wierszy dla dzieci, poprzez dzieła klasyków poezji, na prozie kończąc; 4) folklor, to jest bogactwo przysłów i porzekadeł, zwyczajów, opowieści zawierających elementy słownictwa mykologicznego, co ważne, właśnie w odmianach regionalnych.

Nakreślenie obszarów badawczych oraz przegląd źródeł są pierwszym etapem, rzecz jasna otwartym, zmierzenia się z problematyką funkcjonowania słownictwa mykologicznego w obu systemach językowych. Jednakże dopiero kolejne fazy prac, mogące bazować na przytoczonych tu pozycjach, będą stanowić właściwą realizację zadań i poruszonych tu zagadnień.

\section{Bibliografia}

Baran E., Zarys mikologii lekarskiej, Volumed, Wrocław 1998.

Bartnicka-Dąbkowska B., Polskie ludowe nazwy grzybów, Zakład Narodowy im. Ossolińskich, Wrocław-Warszawa-Kraków 1964.

Bielawski L., Mioduchowska A., Kaszuby, cz. 1. Pieśni obrzędowe, „Polska pieśń i muzyka ludowa. Źródła i materiały" 2, Warszawa 1997.

Brzechwa J., Grzyby, Firma Księgarska Olesiejuk, Warszawa 2014, s. 3-10.

Chlebicki A., Zawiłości etymologiczne i znaczeniowe nazw ,huba” $i$, hubka”, „Wiadomości Botaniczne" 54 (1/2), 2010.

Gumińska B., Atlas grzybów Pienińskiego Parku Narodowego, Pieniński Park Narodowy, Krościenko nad Dunajcem 2006.

Gumińska B., Grzyby wielkoowocnikowe (macromycetes), [w:] Flora i fauna Pienin, red. J. Razowski, „Monografie Pienińskie” 1, Pieniński Park Narodowy, Kraków 2000.

Gumińska B., Macromycetes tąk w Pienińskim Parku Narodowym, „Acta Mycologica” 12 (1), 1976.

Gumińska B., Podstawczaki (Basidiomycetes), wodnichowate (Hygrophoraceae), „Flora Polski” 26, Wydawnictwo Uniwersytetu Jagiellońskiego, Kraków 1997.

Gumińska B., Wojewoda W., Grzyby i ich oznaczanie, wyd. 3, Państwowe Wydawnictwo Rolnicze i Leśne, Warszawa 1985.

Kamiński W., Flaczyńska M., Encyklopedia grzybów w Polsce, PWN, Warszawa 2015.

Kochman J., Zarys mikologii dla fitopatologów, Wydawnictwa Akcydensowe, Warszawa 1981.

Kopczyński K., Ławrynowicz M., Polskie regionalne nazwy grzybów, [w:] Monitoring grzybów, red. M. Lisiewska, M. Ławrynowicz, Unidruk, Poznań-Łódź 2000.

Kuźmiuk J., Etymologia nazw grzybów znanych na Białostocczyźnie, „Białostocczyzna” 8/2 (30), 1993.

Kuźmiuk J., Nazwy grzybów w języku potocznym okolic Bielska Podlaskiego, „Białostocczyzna” 4/4 (16), 1989. 
Kuźmiuk J., Nazwy niektórych grzybów w gwarach między Bugiem a Narwia, [w:] Badania dialektów i onomastyki na pograniczu polsko-wschodniostowiańskim, UW. Filia w Białymstoku. Zakład Filologii Wschodniosłowiańskich, Białystok 1995.

Kuźmiuk J., Regionalne nazwy grzybów jadalnych między Biebrza a Narwia na Białostocczyźnie, „Białostocczyzna” 6/2 (22), 1991.

Libudzisz Z., Kowal K., Żakowska Z., Mikrobiologia techniczna, PWN, Warszawa 2007.

Marcinkowska J., Oznaczanie rodzajów grzybów ważnych w patologii roślin, Fundacja „Rozwój SGGW", Warszawa 2003.

Mickiewicz A., Pan Tadeusz, księga 3. Umizgi, Czytelnik, Warszawa 1984, s. 81-82.

Miszczak Z.M., O czym Jaś nie przeczytat $w$ atlasie, http://wierszykidladzieci.pl/miszczak/atlasgrzybow.php.

Nowa księga przysłów polskich, red. J. Krzyżanowski, PWN, Warszawa 1969.

Referowska-Chodak E., „Studia i materiały CEPL w Rogowie” 3, 2015, z. 44.

Ożogowska H., A to kapelusz, [w:] Wierszyki dla dzieci, Podsiedlik-Raniowski i S-ka, Warszawa 2001.

Skirgiełło A., Grzyby niższe. Pragrzyby i glonowce. Przewodnik morfologiczno-systematyczny z kluczami do oznaczania, PWN, Warszawa 1954.

Skirgiełło A., Nasze grzyby, Wydawnictwa ALFA, Warszawa 1990.

Skirgiełło A., Polskie naziemne grzyby rurkowe, „Planta Polonica” 8 (3), 1939.

Skirgiełło A., Rodzaj Russula w Polsce i w krajach przylegtych, „Planta Polonica” 9 (1), 1951.

Skirgiełło A., Wiosenne miseczniaki Białowieży, „Monographiae Botanicae” 10 (2), 1960.

Stownik języka polskiego, red. W. Doroszewski, PWN, Warszawa 1996.

Stownik języka polskiego, red. M. Szymczak, PWN, Warszawa 1998.

Snowarski M., Grzyby, Multico Oficyna Wydawnicza, Warszawa 2014.

Sztaudynger J.I. , Do borowika, Boletus rufus, Do maślaka, Opinia i rzeczywistość, Kurki, Bajka o grzybach, Do towarzyszy grzybiarzy, Niewdzięcznik i in., https://idziemy.nagrzyby.pl/index. php? artname $=$ stories\&artmid $=$ content\&id $=2519$.

Szuchowa S., Borowik, http://przedszkolak.blogspot.com/2007/10/wiersz-borowik.html.

Sokół S., Atlas grzybów, Wydawnictwo Olesiejuk, Ożarów Mazowiecki 2015.

Terlikowska M., Jestem jesień, http://dzieci.epapa.pl/wiersze/7037.html.

Uniwersalny słownik języka polskiego, red. S. Dubisz, PWN, Warszawa 2008.

Wojewoda W., Grzyby, [w:] Przyroda Popradzkiego Parku Krajobrazowego, Zarząd Popradzkiego Parku Krajobrazowego, Stary Sącz 2000.

Wojewoda W., Grzyby wielkoowocnikowe, „Przyroda Ojcowskiego Parku Narodowego”, „Studia Naturae Ser. B.”28, 1977.

Wojewoda W., ,,Mikologia” czy „mykologia”?, „Wiadomości Botaniczne” 17 (3), 1973.

Wojewoda W., O grzybach jadalnych i trujacych, „Nauka dla wszystkich” 104, 1970.

Wojewoda W., Podręczny atlas grzybów, Państwowe Wydawnictwo Rolnicze i Leśne, Warszawa 1992.

Wojewoda W., Poradnik grzybiarza, Prószyński i S-ka, Warszawa 2012.

Zarawska P., Atlas grzybów, Wydawnictwo SBM, Warszawa 2013.

Ботаніка. Водорості та гриби, за ред. І.Ю. Костікова і В.В. Джаган, Арістей, Київ 2006.

Вассер С., Флора грибів України. Агарікові гриби, Наукова думка, Київ 1980.

Вассер С., Нижчі рослини, гриби і мохоподібні радянського Далекого Сходу, Наука, Київ 1990.

Гриби природних зон Криму (під заг. ред. І.О. Дудки), Фітосоціоцентр, Київ 2004.

Дудка I., Вассер С., Гриби в природі та житті людини, Наукова думка, Київ 1980.

Дудка I., Вассер С., Довідник міколога і грибника, Наукова думка, Київ 1987.

Дудка І., Гелюта В.П., Андріанова Т.В. та ін., Гриби заповідників та національних природних парків Лівобережної України, Арістей, Київ 2009. 
Дудка І.О., Придюк М.П., Голубцова Ю.І., Андріанова Т.В., Карпенко К.К., Гриби та грибоподібні організми національного природного парку "Деснянсько-Старогутський», Університетська книга, Суми 2009.

Зерова М., Їстівні та отруйні гриби Украӥни, Наукова думка, Київ 1963, 1970.

Зерова М., Атлас грибів України, Наукова думка, Київ 1974.

Зерова М., Гриби. Їстівні, умовно їстівні, неїстівні, отруйні, Урожай, Київ 1984.

Зерова М., Вассер С., Їстівні та отруйні гриби Карпатських лісів, Карпати, Ужгород 1972.

Жадан С., Гриби Донбасу, http://tisk.org.ua/?p=13188.

Калинець-Мамчур 3., Словник-довідник з альгології та мікології, ЛНУ імені Івана Франка, Львів 2011.

Капустюк Н., Бліда поганка, Боровик, Маслюк і in., http://allforchildren.com.ua/index_mushrooms1.htm.

Куриленко В. М., Гриби - губи: полісемія чи омонімія? (на матеріалі лексики поліських говоpiв), „Записки з українського мовознавства” вип. 16, Основа, Одеса 2006.

Леонтьев Д.В., Акулов А.Ю., Загальна мікологія, Основа, Харків 2008.

Мавров I.І., Безрученко І.А., Калюжна Л.Д., Культуральна діагностика дерматомікозів: Методичні рекомендації, Знання України, Київ 2004.

Марков І.Л., Практикум із сільськогосподарської фітопатології, ННЦ „ІАЕ”, Київ 2011.

Немирович I., Кабан і гриби, http://gumoreska.org.ua/baiki/baiki-virshi/277-kaban-gribi.html.

Омельковець Р., Семантична трансформація як спосіб номінації мікооб'єктів у західнополіських говірках, „Типологія та функції мовних одиниць” № 1, Східноєвроп. нац. ун-т ім. Лесі Українки, Луцьк 2014.

Прокоф'єв О., Боровик, Опеньок i in., http://allforchildren.ru/poetry/index_mushrooms.php.

Симоненко Л.О., Синонімічні назви грибів в украӥнській мові, „Рідне слово” Вип. 7, Київ 1973. Симоненко Л.О., Як назвати гриби?, „Рідне слово” Вип. 9, Київ 1974.

Степанов В., Маслюки, Підберезник і підосичник i in., http://allforchildren.com.ua/mushrooms0141.htm.

Сухомлин М.М., Джаган В.В., Гриби Украӥни, Видавництво „Країна мрій”, Київ 2013.

Ткачук М., Мікономінація в чорнобильських говірках (питання реконструкиії ареалу), „Волинь - Житомирщина” № 22 (2), 2010.

Черниш Т.О., Нариси зі слов 'янської порівняльно-історичної лексикології та етимології, ВПЦ „Київський університет”, Київ 2010.

Чорновіл Т., Сироїжки, Маслюк, Глива, Опеньок, Боровик, Зеленуха, Польський гриб і in., http://probapera.org/publication/13/6578/virshyky-u-koshyku.html.

Шульжик В., Дощзовик, Мухомор і in., http://allforchildren.com.ua/mushrooms0141.htm.

Єлін Ю.Я., Зерова М.Я., Лушпа В.І., Шабарова С.І., Дари лісів Украйни, Урожай, Київ 1975.

\section{Źródła internetowe}

http://cybertruffle.org.uk/ukrafung/ukr/.

http://grzyby.pl.

http://nagrzyby.pl.

http://plus.gazetawroclawska.pl/opinie/a/rzecz-o-jezyku-laknac-jak-kania-dzdzu,12311511.

https://web.archive.org/web/20090416234856/http://www.huh.harvard.edu/libraries/wasson.html. http://www.rjp.pan.pl/index.php?option=com_content\&view $=$ article $\& i d=681$ :akn-jak-kania-ddu\&catid=44\&Itemid=145. 


\section{On the Terminology of Macrofungi in Ukrainian and Polish. An Overview of Sources}

\section{Summary}

The aim of this article was to discuss Ukrainian and Polish sources of mycological vocabulary and to highlight the necessity of initiating a scholarly discourse on this subject. The analyzed vocabulary (especially myconims) appears in numerous scholarly texts (not only mycological), popular science books, literature, as well as in folklore. Each of these areas provides a linguist with a potential source of data since linguistic research can be conducted in many fields (i.e. paremiology, dialectology, terminology, etymology).

Keywords: the Ukrainian language, mycological vocabulary, comparative linguistics, overview of sources, research overview

\section{3 проблем найменивання макроміцетів в українській і польській моwax - огляд джерел}

Резюме

Названо і обговорено українські та польські джерела мікологічної лексики, а також обгрунтовано необхідність започаткувати мовознавчі дослідження у цій галузі. Функціонування мікологічної лексики на рівні тексту, зокрема міконімів, зводиться до ії присутності в наукових (з різних галузей, не тільки у мікологічних працях) і науково-популярних роботах, в літературних текстах, у сфері фольклору. Кожна з названих ділянок - це для мовознавця потенційне джерело потужних лексичних ресурсів, а мовознавчі дослідження можна буде вести на багатьох рівнях (пареміологія, діалектологія, термінологія, етимологія тощо).

Ключові слова: українська і польська мови, мікологічна лексика, зіставне мовознавство, фольклор, художні тексти, науково-популярні роботи 